\title{
Apolipoprotein E polymorphism distribution in an elderly Brazilian population: the Bambuí Health and Aging Study
}

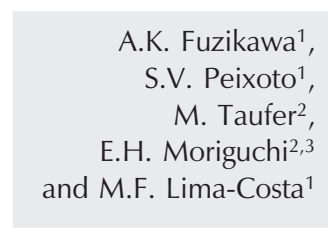

\section{Correspondence}

M.F. Lima-Costa

Laboratório de Epidemiologia e

Antropologia Médica

Centro de Pesquisas René Rachou

Fundação Oswaldo Cruz

Av. Augusto de Lima, 1715

30190-002 Belo Horizonte, MG

Brasil

Fax: +55-31-3295-3115

E-mail: lima-costa@cpqrr.fiocruz.br

Research supported by $\mathrm{CNPq}$

(No. 470841/2004-4).

Received January 31, 2007

Accepted August 7, 2007

\author{
${ }^{1}$ Núcleo de Estudos em Saúde Pública e Envelhecimento, \\ Instituto René Rachou, Fundação Oswaldo Cruz, Faculdade de Medicina, \\ Universidade Federal de Minas Gerais, Belo Horizonte, MG, Brasil \\ ${ }^{2} \mathrm{CMIC}$ Brasil Pesquisas Clínicas, Porto Alegre, RS, Brasil \\ ${ }^{3}$ Hospital de Clínicas de Porto Alegre, Universidade Federal do Rio Grande do Sul, \\ e Hospital Moinhos de Vento de Porto Alegre, Porto Alegre, RS, Brasil
}

\begin{abstract}
Apolipoprotein E (ApoE) is one of the most extensively studied genes in the context of aging, but there are few population-based studies on ApoE polymorphism in the elderly in developing countries. The objective of the present study was to assess ApoE allele and genotype distribution in a large elderly community-based sample and its association with age, sex and skin color. Participants included 1408 subjects $(80.8 \%$ of all residents aged $\geq 60$ years) residing in Bambuí city, MG, Brazil. The DNA samples were subjected to the polymerase chain reaction amplification, followed by the restriction fragment length polymorphism technique, with digestion by HhaI. Analysis was carried out taking into consideration the six ApoE genotypes ( $\varepsilon 3 /$ $\varepsilon 3, \varepsilon 3 / \varepsilon 4, \varepsilon 2 / \varepsilon 3, \varepsilon 4 / \varepsilon 4, \varepsilon 2 / \varepsilon 4$, and $\varepsilon 2 / \varepsilon 2$ ), the three ApoE alleles, and the number of ApoE4 alleles for each individual. The $\varepsilon 3$ allele predominated (80.0\%), followed by $\varepsilon 4(13.5 \%)$ and $\varepsilon 2$ (6.5\%). All six possible genotypes were observed, the $\varepsilon 3 / \varepsilon 3$ genotype being the most frequent $(63.4 \%)$. This distribution was similar to that described in other western populations. Sex was not associated with number of ApoE4 alleles. Black skin color was significantly and independently associated with the presence of two ApoE4 alleles (age-sex adjusted $\mathrm{OR}=7.38$; $95 \% \mathrm{CI}=1.93-28.25$ ), showing that the African-Brazilian elderly have a high prevalence of the $\varepsilon 4$ allele, as observed in blacks from Africa. No association between number of ApoE4 alleles and age was found, suggesting the absence of association of ApoE genotype with mortality in this population.
\end{abstract}

\section{Introduction}

The search for genes and mutations potentially linked to diseases and aging itself has revealed many candidates. One of the genes most extensively studied in the context of aging has been the apolipoprotein $\mathrm{E}$
Key words

- Apolipoprotein E

- Elderly

- Prevalence

- Brazil gene (ApoE), located on chromosome 19, which encodes for a protein that participates in the regulation of lipid metabolism (1-3).

The ApoE gene is polymorphic, containing single-nucleotide polymorphisms, which are mutations leading to changes in a single nucleotide base in the DNA sequence of the gene, 
eventually causing changes in the amino acid sequence of the protein. Studies have shown that there are three common $A p o E$ alleles in populations throughout the world, known as $\varepsilon 2$, $\varepsilon 3$, and $\varepsilon 4$, giving rise to 6 genotypes ( $\varepsilon 2 /$ $\varepsilon 2$, $\varepsilon 2 / \varepsilon 3, \varepsilon 2 / \varepsilon 4, \varepsilon 3 / \varepsilon 3, \varepsilon 3 / \varepsilon 4$, and $\varepsilon 4 / \varepsilon 4)$. Allelic frequencies vary widely, with $\varepsilon 3$ being the most common (wild type), while $\varepsilon 4$ is more frequent in certain populations from Africa (4-6), northern Europe (5,7), Oceania (7), and in native Americans $(8,9)$.

ApoE has multiple other roles in addition to its role in lipid metabolism (10) and the presence of the $\varepsilon 4$ allele has been consistently linked to the development of Alzheimer's disease (11). This allele has also been associated with coronary heart disease (12, 13 ) and cerebrovascular disease $(14,15)$ in some studies but not in others $(16,17)$. In addition, ApoE has been studied in the context of mortality, but the results of these studies are controversial (18-24).

Community-based studies on ApoE polymorphism conducted in well-defined Brazilian populations are scarce (25), and all of them were small, involving populations of less than 500 subjects $(8,9,25-30)$. The present study describes ApoE allele and genotype distribution in an elderly communitybased sample of 1408 subjects, and its association with age, gender and skin color.

\section{Material and Methods}

\section{Study area}

The city of Bambuí (approximately 15,000 inhabitants) is situated in the Southwestern region of the State of Minas Gerais. Cerebrovascular diseases constitute the main cause of death in the population aged $\geq 60$ years, followed by Chagas' disease and ischemic heart diseases. The Bambuí Health and Ageing Study (BHAS) is a populationbased cohort study of older adults which is being conducted in Bambuí since 1997. In this report, we analyze data collected at the baseline of this study.

The Bambuí cohort study was approved by the Ethics Committee of the Oswaldo Cruz Foundation in Rio de Janeiro in 1996, and the present project was approved by the Ethics Committee of the Oswaldo Cruz Foundation in Belo Horizonte in 2006. All participants gave informed written consent.

\section{Study population}

From November to December 1996, a census was conducted in Bambuí to identify participants for the baseline study. Every person aged 60 years or older $(\mathrm{N}=1742)$ was invited to take part in the study. Of these, 1606 (92\%) were interviewed for risk factors, and 1496 (85.9\%) had blood samples drawn for genomic DNA extraction. The latter subjects comprise the sample for the present study. Additional details have been reported elsewhere (31).

\section{DNA extraction, PCR amplification and RFLP genotyping}

Genomic DNA was extracted from the blood samples using the Wizard genomic DNA extraction kit (Promega, Madison, WI, USA). Samples were stored at $-70^{\circ} \mathrm{C}$ until further use. $A p o E$ genotyping was carried out as described by Hixson and Vernier (32), with slight modifications. The DNA samples were subjected to the polymerase chain reaction amplification, using the following primers: forward 5' TAA GCT TGG CAC GGC TGT CCA AGG A 3' and reverse 5' ACA GAA TTC GCC CCG GCC TGG TAC AC 3'. Polymerase chain reaction conditions were denaturation at $95^{\circ} \mathrm{C}$ for $5 \mathrm{~min}$, followed by 35 cycles of $95^{\circ} \mathrm{C}$ for 1 $\min , 60^{\circ} \mathrm{C}$ for $1 \mathrm{~min}$, and $70^{\circ} \mathrm{C}$ for $2 \mathrm{~min}$, and a final extension at $72^{\circ} \mathrm{C}$ for $10 \mathrm{~min}$. The amplified DNA was subjected to the restriction fragment length polymorphism technique, with digestion by $H$ haI, generating the following patterns: $\varepsilon 2 \varepsilon 2,83$ and 91 bp; $\varepsilon 3 \varepsilon 3,91,48$, and $35 \mathrm{bp}$, and $\varepsilon 4 \varepsilon 4,72,48,35$, and $19 \mathrm{bp}$. 
These fragments were visualized on $4 \%$ agarose gels, instead of polyacrylamide gels as described in the original article.

\section{Variables}

In the present study, the dependent variable was the single-nucleotide polymorphism of the $A p o E$ gene. Analysis was carried out taking into consideration the three ApoE alleles, the six $A p o E$ genotypes ( $\varepsilon 3 / \varepsilon 3, \varepsilon 3 /$ $\varepsilon 4, \varepsilon 2 / \varepsilon 3, \varepsilon 4 / \varepsilon 4, \varepsilon 2 / \varepsilon 4$, and $\varepsilon 2 / \varepsilon 2)$ and the number of ApoE4 alleles for each individual ( 0,1 or 2 alleles).

Independent variables included age (60$69,70-79$, and $\geq 80$ years), sex and skin color. Interviewers classified the subjects based on photographs representative of individuals with different skin colors (white, light brown, dark brown, and black).

\section{Statistical analysis}

Statistical analysis was based on Pearson's chi-square test and on multinomial regression (33). Allele frequencies were estimated by gene counting. Hardy-Weinberg equilibrium expectations were tested by using a chi-square goodness-of-fit test. The statistical analysis was performed using the Stata version 7.0 software (Stata Corporation, College Station, TX, USA).

\section{Results}

Of the 1606 BHAS cohort members, 1408 (557 males and 851 females) could be genotyped and participated in this study, their mean age being 69.3 years $(\mathrm{SD}=7.2)$. The participants in this study were similar to non-participants regarding age $(\mathrm{P}=0.999)$, sex $(\mathrm{P}=0.365)$, and skin color $(\mathrm{P}=0.063)$.

The ApoE allele and genotype distribution in the study population is shown in Figure 1. The most frequent allele was $\varepsilon 3(80.0 \%)$, followed by $\varepsilon 4(13.5 \%)$, and $\varepsilon 2$ (6.5\%). The distribution of $A p o E$ alleles was within Hardy-
Weinberg equilibrium $(\mathrm{P}>0.05)$. All six possible genotypes were observed: the $\varepsilon 3 / \varepsilon 3$ genotype predominated $(63.4 \%)$, followed by $\varepsilon 3 /$

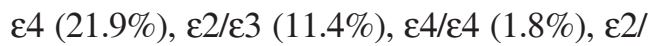
$\varepsilon 4(1.4 \%)$, and $\varepsilon 2 / \varepsilon 2(0.1 \%)$.

There was no statistically significant difference $(P=0.311)$ in allele or genotype distribution among the various age groups (Table 1). The $\varepsilon 3$ allele $(79.4,81.4$, and $79.3 \%$ ) and the $\varepsilon 3 / \varepsilon 3$ genotype predominated in all age groups $(61.8,66.6$, and

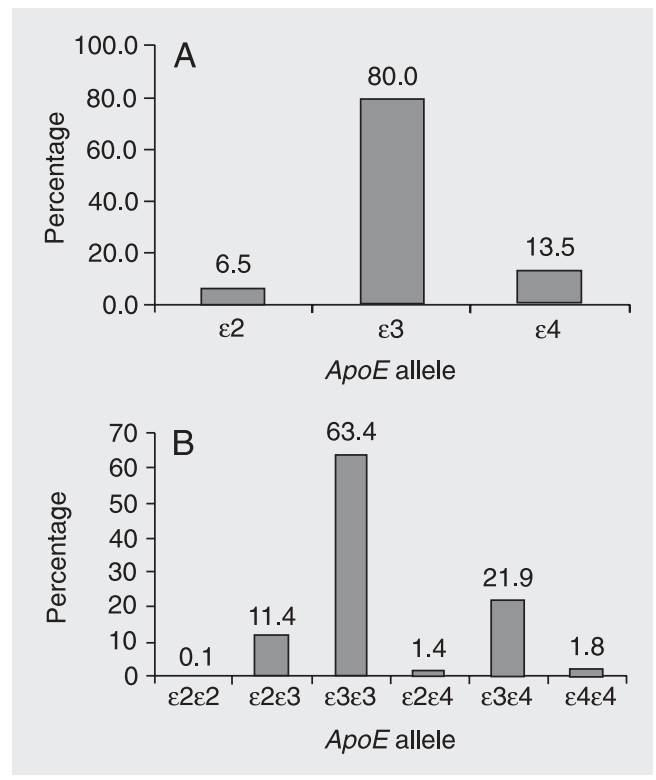

Figure 1. ApoE allele (A) and genotype (B) distribution among 1408 elderly participants at baseline of the Bambuí Health and Aging Study (Brazil).
Table 1. Apolipoprotein $E(A p o E)$ allele and genotype distributions among 1408 elderly participants at baseline of the Bambuí Health and Aging Study by age group (Brazil).

\begin{tabular}{cccc}
\hline ApoE & \multicolumn{3}{c}{ Age group } \\
\cline { 2 - 4 } & $60-69$ years & $70-79$ years & $\geq 80$ years \\
\hline Allele & & & \\
$\varepsilon 2$ & $110(6.6 \%)$ & $58(6.7 \%)$ & $15(5.5 \%)$ \\
$\varepsilon 3$ & $1328(79.4 \%)$ & $707(81.4 \%)$ & $219(79.3 \%)$ \\
$\varepsilon 4$ & $234(14.0 \%)$ & $103(11.9 \%)$ & $42(15.2 \%)$ \\
Genotype & & & \\
$\varepsilon 2 / \varepsilon 2$ & $102(0.0 \%)$ & $1(0.2 \%)$ & $0(0.0 \%)$ \\
$\varepsilon 2 / \varepsilon 3$ & $517(61.8 \%)$ & $289(10.8 \%)$ & $12(8.7 \%)$ \\
$\varepsilon 3 / \varepsilon 3$ & $8(1.0 \%)$ & $9(2.1 \%)$ & $86(62.3 \%)$ \\
$\varepsilon 2 / \varepsilon 4$ & $192(23.0 \%)$ & $82(18.9 \%)$ & $35(2.2 \%)$ \\
$\varepsilon 3 / \varepsilon 4$ & $17(2.0 \%)$ & $6(1.4 \%)$ & $2(1.4 \%)$ \\
$\varepsilon 4 / \varepsilon 4$ & & & $35 \%)$ \\
\hline
\end{tabular}

Data are reported as number with percent in parentheses. $A p o E: P=0.481$, genotype: $P=0.311$ (Pearson's chi-square test). 
$62.3 \%$ among subjects aged 60-69, 70-79 and $\geq 80$ years, respectively).

The distribution of the number of ApoE4 alleles according to demographic characteristic is shown in Table 2. A significant association between number of $\varepsilon 4$ alleles and skin color was found $(\mathrm{P}=0.023)$, but no associations with age $(\mathrm{P}=0.437)$ or sex $(\mathrm{P}=$ $0.394)$ were observed. The prevalence of two $\varepsilon 4$ alleles among black and dark brown subjects was 9.1 and $4.1 \%$, respectively, while among light brown and white subjects the prevalence was less than $2 \%$. The association between black skin color and two $\varepsilon 4$ alleles was strong and independent of sex and age $(\mathrm{OR}=7.38 ; 95 \% \mathrm{CI}=1.93-28.25)$.

\section{Discussion}

The results of the present study show that $\varepsilon 3 / \varepsilon 3$ was the most frequent genotype and $\varepsilon 3$ was the most frequent allele in the study population. These results are in agreement with previous observations that $\varepsilon 3$ is the most common allele worldwide $(5,7)$.

Regarding the $\varepsilon 4$ and $\varepsilon 2$ alleles, some differences in distribution have been reported. In Europe, studies have described a north to south cline in the $\varepsilon 4$ allele, with a higher frequency in the northern region and a lower frequency in the southern region $(7,34,35)$. The highest frequencies of $\varepsilon 4$ have been described in Nigerians (4), Sub-Saharan Africans (5), South Africans (6), Inuit from Greenland (7), Finns (7), and native Americans (up to $47 \%$ in Brazilian natives) (8). $\varepsilon 2$ is the least frequent allele, being completely absent from certain populations, in particular from several Native American tribes $(8,9,26)$. In the present study, the prevalence of the $\varepsilon 4$ and $\varepsilon 2$ alleles was 13.5 and $6.5 \%$, respectively.

In Brazil, studies carried out in children have found similar allele distributions. In Recife city (northeastern Brazil), allele distribution among 414 children ascertained at a pediatric hospital was as follows: $\varepsilon 3,77 \%$; $\varepsilon 4$, $17 \%$, and $\varepsilon 2,6 \%$ (27). In Fortaleza city, also in northeastern Brazil, the corresponding findings among 72 shantytown children were 77.1, 14.6, and $8.3 \%$, respectively (28). Previous studies of ApoE polymorphism in small samples of native Brazilian and South Ameri-

Table 2. Association of the number of ApoE4 alleles among 1408 elderly participants at baseline of the Bambuí Health and Aging Study with selected demographic characteristics (Brazil).

\begin{tabular}{|c|c|c|c|c|c|}
\hline \multirow[t]{2}{*}{ Variables } & \multicolumn{5}{|c|}{ Number of ApoE4 alleles } \\
\hline & $\begin{array}{l}\text { None } \\
\mathrm{N}(\%)\end{array}$ & $\begin{array}{l}\text { One } \\
N(\%)\end{array}$ & $\begin{array}{l}\text { Two } \\
\mathrm{N}(\%)\end{array}$ & $\begin{array}{c}\text { One } \\
\text { OR }(95 \% \mathrm{Cl})^{*}\end{array}$ & $\begin{array}{c}\text { Two } \\
\text { OR }(95 \% \mathrm{Cl})^{*}\end{array}$ \\
\hline \multicolumn{6}{|l|}{ Age group (years) } \\
\hline $60-69$ years & $619(74.1 \%)$ & $200(23.9 \%)$ & $17(2.0 \%)$ & 1.00 & 1.00 \\
\hline $70-79$ years & $337(77.6 \%)$ & $91(21.0 \%)$ & $6(1.4 \%)$ & $0.83(0.62-1.10)$ & $0.69(0.27-1.79)$ \\
\hline$\geq 80$ years & $98(71.0 \%)$ & $38(27.5 \%)$ & $2(1.5 \%)$ & $1.17(0.78-1.76)$ & $0.73(0.16-3.24)$ \\
\hline \multicolumn{6}{|l|}{ Gender } \\
\hline Female & 643 (75.6\%) & $196(23.0 \%)$ & 12 (1.4\%) & 1.00 & 1.00 \\
\hline Male & $411(73.8 \%)$ & $133(23.9 \%)$ & $13(2.3 \%)$ & $1.05(0.82-1.36)$ & $1.65(0.74-3.67)$ \\
\hline \multicolumn{6}{|l|}{ Skin color } \\
\hline White & $630(74.2 \%)$ & $207(24.4 \%)$ & $12(1.4 \%)$ & 1.00 & 1.00 \\
\hline Light brown** & $368(77.1 \%)$ & $101(21.2 \%)$ & $8(1.7 \%)$ & $0.84(0.64-1.10)$ & $1.11(0.45-2.76)$ \\
\hline Dark brown ${ }^{* *}$ & $35(71.4 \%)$ & $12(24.5 \%)$ & $2(4.1 \%)$ & $1.04(0.53-2.04)$ & $2.87(0.61-13.35)$ \\
\hline Black & $21(63.6 \%)$ & $9(27.3 \%)$ & $3(9.1 \%)$ & $1.30(0.59-2.89)$ & $7.38(1.93-28.25)$ \\
\hline
\end{tabular}

$A p o E=$ apolipoprotein $\mathrm{E} ; \mathrm{OR}=$ odds ratio; $95 \% \mathrm{Cl}=$ confidence interval at $95 \%$. Age group: $\mathrm{P}=0.437$, sex: $\mathrm{P}$ $=0.394$, skin color: $\mathrm{P}=0.023$ (Pearson chi-square test).

*Adjusted by multinomial logistic regression for the variables listed in the table (absence of $\varepsilon 4$ allele was the reference group). " ${ }^{*}$ Light brown: "moreno"; dark brown: "mulatto". 
can populations $(8,9,26,29)$ found a highly heterogeneous distribution of alleles with a predominance of $\varepsilon 3$ (frequency range: 51$98 \%)$, followed by $\varepsilon 4(0-47 \%)$ and $\varepsilon 2(0-4 \%)$.

Regarding older subjects, two Brazilian studies were carried out in the State of Rio Grande do Sul, in the south of Brazil $(25,30)$. One involved a random sample of 64 subjects aged 80 years and older from a population of Italian descent residing in the city of Veranópolis. ApoE allelic frequencies were $\varepsilon 3,84 \% ; \varepsilon 4,11 \%$, and $\varepsilon 2,5 \%$, and only four genotypes were observed: $\varepsilon 3 / \varepsilon 3(70 \%), \varepsilon 3 /$ $\varepsilon 4$ (22\%), ع3/ع2 (6\%), and $\varepsilon 2 / \varepsilon 2$ (2\%) (25). The other study involved 252 Caucasian volunteers $\geq 50$ years of age residing in the city of Gravataí. ApoE allelic frequencies for this population were $\varepsilon 3,76.7 \%$; $\varepsilon 4,16.2 \%$, and $\varepsilon 2,7.1 \%$, with five genotypes ( $\varepsilon 2$ homozygotes were absent), $\varepsilon 3 / \varepsilon 3$ being the most frequent $(61.3 \%)$, followed by $\varepsilon 3 / \varepsilon 4$ $(24.3 \%)(30)$.

The allelic frequencies found in the present study are similar to the distributions found among older adults from south Brazil $(25,30)$, even though the population from Bambuí is miscigenated and somewhat different from the populations in these studies which have a more strict European ascendance.

Reports that have included blacks from Africa (4-6) have suggested that there may be a higher frequency of the $\varepsilon 4$ allele in blacks but, to the best of our knowledge, there are no population-based studies of ApoE polymorphisms in African-Brazilians. In our study, we found a gradient in the prevalence of $\varepsilon 4$ homozygotes when genotypes were compared by skin color, with the highest prevalence among black-skinned individuals and the lowest among white-skinned subjects. Black-skinned individuals from this sample were significantly more likely to be $\varepsilon 4$ homozygotes compared to white-skinned individuals. Among the dark-brown-skinned individuals the prevalence of $\varepsilon 4$ homozygotes was twice as high as among whiteskinned subjects, but this difference was not statistically significant. Those results could be the consequence of the greater $\varepsilon 4$ prevalence mentioned above among African subjects, groups of which were brought to Brazil by the Portuguese during the 15th to 18th centuries as slaves, and which now form an important part of the Brazilian gene pool (8).

Several studies have investigated the association between $\varepsilon 4$ allele and age. If an association of $\varepsilon 4$ and mortality existed, one would expect to find a lower prevalence of this allele among the very old. Previously published results have been controversial, with some investigators reporting lower frequencies of $\varepsilon 4$ among the very old (19-21), a finding which was not replicated by others (22-24). In the present study, we did not identify an association between $\varepsilon 4$ allele prevalences and age.

This paper presents the largest populationbased study on $A p o E$ distribution carried out in Brazil, involving 1408 individuals who represent a well-defined target population. The results of the present study showed a distribution of $A p o E$ alleles and genotypes similar to those observed in other western populations. The distribution of ApoE alleles was influenced by skin color, showing that the AfricanBrazilian elderly in the study population have a high prevalence of the $\varepsilon 4$ allele, as observed in blacks from Africa (4-6). The distribution of ApoE4 alleles was not influenced by age, suggesting the absence of association with mortality in the study population.

\section{References}

1. Das HK, McPherson J, Bruns GA, Karathanasis SK, Breslow JL. Isolation, characterization, and mapping to chromosome 19 of the human apolipoprotein E gene. J Biol Chem 1985; 260: 6240-6247.
2. Paik YK, Chang DJ, Reardon CA, Davies GE, Mahley RW, Taylor JM. Nucleotide sequence and structure of the human apolipoprotein E gene. Proc Natl Acad Sci U S A 1985; 82: 3445-3449. 
3. Mahley RW, Innerarity TL, Rall SC Jr, Weisgraber KH. Plasma lipoproteins: apolipoprotein structure and function. J Lipid Res 1984; 25: 1277-1294.

4. Sepehrnia B, Kamboh MI, Adams-Campbell LL, Nwankwo M, Ferrell RE. Genetic studies of human apolipoproteins. VII. Population distribution of polymorphisms of apolipoproteins A-I, A-II, A-IV, C-II, E, and $\mathrm{H}$ in Nigeria. Am J Hum Genet 1988; 43: 847-853.

5. Hallman DM, Boerwinkle E, Saha N, Sandholzer C, Menzel HJ, Csazar A, et al. The apolipoprotein E polymorphism: a comparison of allele frequencies and effects in nine populations. Am J Hum Genet 1991; 49: 338-349.

6. Sandholzer C, Delport R, Vermaak H, Utermann G. High frequency of the apo $\varepsilon 4$ allele in Khoi San from South Africa. Hum Genet 1995; 95: $46-48$.

7. Gerdes LU, Gerdes C, Hansen PS, Klausen IC, Faergeman O, Dyerberg J. The apolipoprotein E polymorphism in Greenland Inuit in its global perspective. Hum Genet 1996; 98: 546-550.

8. de Andrade FM, Coimbra CE Jr, Santos RV, Goicoechea A, Carnese FR, Salzano FM, et al. High heterogeneity of apolipoprotein E gene frequencies in South American Indians. Ann Hum Biol 2000; 27: 2934.

9. Demarchi DA, Salzano FM, Altuna ME, Fiegenbaum M, Hill K, Hurtado AM, et al. APOE polymorphism distribution among Native Americans and related populations. Ann Hum Biol 2005; 32: 351365.

10. Mahley RW. Apolipoprotein E: cholesterol transport protein with expanding role in cell biology. Science 1988; 240: 622-630.

11. Farrer LA, Cupples LA, Haines JL, Hyman B, Kukull WA, Mayeux R, et al. Effects of age, sex, and ethnicity on the association between apolipoprotein $\mathrm{E}$ genotype and Alzheimer disease. A meta-analysis. APOE and Alzheimer Disease Meta Analysis Consortium. JAMA 1997; 278: 1349-1356.

12. Wilson PW, Schaefer EJ, Larson MG, Ordovas JM. Apolipoprotein E alleles and risk of coronary disease. A meta-analysis. Arterioscler Thromb Vasc Biol 1996; 16: 1250-1255.

13. Song Y, Stampfer MJ, Liu S. Meta-analysis: apolipoprotein E genotypes and risk for coronary heart disease. Ann Intern Med 2004; 141: 137-147.

14. Margaglione M, Seripa D, Gravina C, Grandone E, Vecchione G, Cappucci G, et al. Prevalence of apolipoprotein $E$ alleles in healthy subjects and survivors of ischemic stroke: an Italian Case-Control Study. Stroke 1998; 29: 399-403.

15. Kokubo Y, Chowdhury AH, Date C, Yokoyama T, Sobue H, Tanaka $\mathrm{H}$. Age-dependent association of apolipoprotein $\mathrm{E}$ genotypes with stroke subtypes in a Japanese rural population. Stroke 2000; 31: 1299-1306.

16. Volcik KA, Barkley RA, Hutchinson RG, Mosley TH, Heiss G, Sharrett AR, et al. Apolipoprotein $E$ polymorphisms predict low density lipoprotein cholesterol levels and carotid artery wall thickness but not incident coronary heart disease in 12,491 ARIC study participants. Am J Epidemiol 2006; 164: 342-348.

17. Luthra K, Prasad K, Kumar P, Dwivedi M, Pandey RM, Das N. Apolipoprotein $\mathrm{E}$ gene polymorphism in cerebrovascular disease: a case-control study. Clin Genet 2002; 62: 39-44.

18. Gerdes LU, Jeune B, Ranberg KA, Nybo H, Vaupel JW. Estimation of apolipoprotein $\mathrm{E}$ genotype-specific relative mortality risks from the distribution of genotypes in centenarians and middle-aged men: apolipoprotein E gene is a "frailty gene," not a "longevity gene". Genet Epidemiol 2000; 19: 202-210.

19. Heijmans BT, Westendorp RG, Slagboom PE. Common gene variants, mortality and extreme longevity in humans. Exp Gerontol 2000; 35: 865-877.

20. Ewbank DC. Mortality differences by APOE genotype estimated from demographic synthesis. Genet Epidemiol 2002; 22: 146-155.

21. Corder EH, Lannfelt L, Viitanen M, Corder LS, Manton KG, Winblad $B$, et al. Apolipoprotein $E$ genotype determines survival in the oldest old (85 years or older) who have good cognition. Arch Neurol 1996; 53: 418-422.

22. Lee JH, Tang MX, Schupf N, Stern Y, Jacobs DM, Tycko B, et al. Mortality and apolipoprotein $\mathrm{E}$ in Hispanic, African-American, and Caucasian elders. Am J Med Genet 2001; 103: 121-127.

23. Louhija J, Viitanen M, Aguero-Torres H, Tilvis R. Survival in Finnish centenarians in relation to apolipoprotein $\mathrm{E}$ polymorphism. J Am Geriatr Soc 2001; 49: 1007-1008.

24. Slooter AJ, Cruts M, Van Broeckhoven C, Hofman A, van Duijin CM. Apolipoprotein E and longevity: the Rotterdam Study. J Am Geriatr Soc 2001; 49: 1258-1259.

25. Schwanke $\mathrm{CH}$, da Cruz I, Leal NF, Scheibe R, Moriguchi Y, Moriguchi EH. Analysis of the association between apolipoprotein $\mathrm{E}$ polymorphism and cardiovascular risk factors in an elderly population with longevity. Arq Bras Cardiol 2002; 78: 561-579.

26. Crews DE, Kamboh MI, Mancilha-Carvalho JJ, Kottke B. Population genetics of apolipoprotein A-4, E, and $\mathrm{H}$ polymorphisms in Yanomami Indians of northwestern Brazil: associations with lipids, lipoproteins, and carbohydrate metabolism. Hum Biol 1993; 65: 211-224.

27. De Franca E, Alves JG, Hutz MH. Apolipoprotein E polymorphism and its association with serum lipid levels in Brazilian children. Hum Biol 2004; 76: 267-275.

28. Oria RB, Patrick PD, Zhang H, Lorntz B, de Castro Costa CM, Brito $\mathrm{GA}$, et al. APOE4 protects the cognitive development in children with heavy diarrhea burdens in Northeast Brazil. Pediatr Res 2005; 57: 310-316.

29. de Andrade FM, Ewald GM, Salzano FM, Hutz MH. Lipoprotein lipase and APOE/APOC-I/APOC-II gene cluster diversity in native Brazilian populations. Am J Hum Biol 2002; 14: 511-518.

30. Gottlieb MG, Schwanke CH, Santos AF, Jobim PF, Mussel DP, da Cruz I. Association among oxidized LDL levels, MnSOD, apolipoprotein E polymorphisms, and cardiovascular risk factors in a south Brazilian region population. Genet Mol Res 2005; 4: 691-703.

31. Lima-Costa MF, Uchoa E, Guerra HL, Firmo JO, Vidigal PG, Barreto SM. The Bambuí health and ageing study (BHAS): methodological approach and preliminary results of a population-based cohort study of the elderly in Brazil. Rev Saúde Pública 2000; 34: 126-135.

32. Hixson JE, Vernier DT. Restriction isotyping of human apolipoprotein $\mathrm{E}$ by gene amplification and cleavage with Hhal. J Lipid Res 1990; 31: 545-548.

33. Hamilton LC. Interpreting multinomial logistic regression. Stata Tech Bull 1993; 13: 24-28.

34. de Knijff $P$, van den Maagdenberg AM, Frants RR, Havekes LM. Genetic heterogeneity of apolipoprotein $E$ and its influence on plasma lipid and lipoprotein levels. Hum Mutat 1994; 4: 178-194.

35. Corbo RM, Scacchi R. Apolipoprotein E (APOE) allele distribution in the world. Is APOE*4 a 'thrifty' allele? Ann Hum Genet 1999; 63: 301-310. 